Short Paper

\title{
Change in Solubility of Carp Myofibrillar Protein by Glycosylation with Ribose
}

\author{
Hiroki Saeki* and Manabu Tanabe \\ Faculty of Fisheries, Hokkaido University, Minato, Hakodate, Hokkaido 041-8611, Japan \\ (Received February 15, 1999)
}

Key words: Carp, myofibrillar protein, neoglycoprotein, lysine, ribose, glycosylation, Maillard reaction, solubility

Glycosylation of protein through the Maillard reaction is an effective method for improving functional properties of proteins. The functionality of food proteins such as bovine serum albumin, ${ }^{17}$ ovalbumin, ${ }^{2)}$ trypsin, ${ }^{37}$ and watersoluble protein fraction of fish muscle ${ }^{4)}$ has been improved by glycosylation with glucose and its derivatives. In addition, Saeki and Inoue ${ }^{5)}$ reported that solubility of carp myofibrillar protein (Mf) in media of low ionic strength was effectively improved by modifying lysine residue with glucose through the Maillard reaction. However, no improvement was observed in the solubility of $\mathrm{Mf}$ in conjugation with polysaccharide, although its thermal stability and emulsifying properties were enhanced. ${ }^{6}$ In this study, the effect of glycosylation with ribose on the solubility of carp $\mathrm{Mf}$ in low ionic strength media was investigated.

Mf $(6.0 \mathrm{mg} / \mathrm{ml})$ prepared from live carp ordinary mus$\mathrm{cle}^{5)}$ was mixed with ribose at a final concentration of 0.3 $M$ and lyophilized. In order to glycosylate protein with ribose through the Maillard reaction, the lyophilized protein powder was incubated at $30^{\circ} \mathrm{C}$ and $65 \%$ relative humidity for $0-8 \mathrm{~h}$. The glycosylated proteins thus obtained were immediately mixed with $0.05-0.5 \mathrm{M} \mathrm{NaCl}$ containing $40 \mathrm{~mm}$ Tris- $\mathrm{HCl}(\mathrm{pH} 7.5)$ at a final protein concentration of 1.5 $\mathrm{mg} / \mathrm{ml}$. The proteins were then homogenized with a highspeed homogenizer. The homogenates were dialyzed against the same $\mathrm{NaCl}$ solution at $4^{\circ} \mathrm{C}$ for $16 \mathrm{~h}$ to remove unreacted ribose, and then they were centrifuged at $15,000 \mathrm{~g}$ at $4^{\circ} \mathrm{C}$ for $30 \mathrm{~min}$. The total solubility of Mf was expressed as the ratio of the protein concentration of the supernatant to that of the homogenate before centrifugation determined by the Biuret method. ${ }^{7}$ The solubilities of myosin and actin were investigated by SDS-polyacrylamide gel electrophoresis with an image scanner. ${ }^{5)}$ The available lysine ${ }^{8)}$ and ketoamine ${ }^{9)}$ contents of Mf were also determined during the reaction.

Figure 1 shows the changes in $\mathrm{NaCl}$ concentration in relation to total solubility upon glycosylation of Mf. Before glycosylation, the total solubility in $0.01-0.1 \mathrm{M} \mathrm{NaCl}$ solutions was $9-12 \%$, and a marked increase was observed in the $\mathrm{NaCl}$ concentration range of $0.16-0.2 \mathrm{M}$. On the other hand, the total solubility of the glycosylated Mf increased remarkably in the $\mathrm{NaCl}$ concentration range of $0.05-0.16$ $M$. Seventy-three percent of the proteins were solubilized in $0.16 \mathrm{M} \mathrm{NaCl}$ when $\mathrm{Mf}$ was reacted for $2 \mathrm{~h}$, and $21 \%$ of

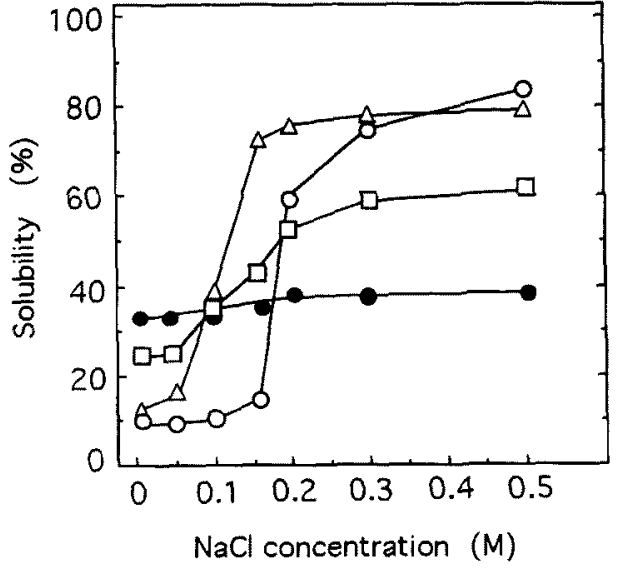

Fig. 1. Change in $\mathrm{NaCl}$ concentration dependence of total solubility of carp Mf.

Glycosylation time: $0 \mathrm{~h}(0), 2 \mathrm{~h}(\triangle), 4 \mathrm{~h}(\square)$, and $8 \mathrm{~h}(\bullet)$.

the lysine residue was modified by ribose. Further, the total solubility of $\mathrm{Mf}$ in $0.01-0.05 \mathrm{M} \mathrm{NaCl}$ increased as glycosylation progressed. The positive effect of glycosylation on protein solubility in $\mathrm{NaCl}$ solutions was obtained by the reaction at $35-50^{\circ} \mathrm{C}$ and confirmed in $\mathrm{KCl}$ solutions (data not shown). These results indicate that the solubility in low ionic strength media was improved by glycosylation with ribose through the Maillard reaction. Thus glycosylation with monosaccharides would be an effective method for solubilizing Mf protein in low ionic strength media.

Glycosylation with ribose improved the solubility of proteins at lower reaction temperatures than glycosylation with glucose, in which $61 \%$ of myosin and $82 \%$ of actin of Mf were solubilized in $0.16 \mathrm{M} \mathrm{NaCl}$ at $40^{\circ} \mathrm{C}$ for $12 \mathrm{~h} .(17 \%$ of available lysine was modified. $\left.{ }^{5}\right)$ In the case of glycosylation with ribose, $72 \%$ of myosin and $80 \%$ of actin were solubilized in $0.16 \mathrm{M} \mathrm{NaCl}$ when $\mathrm{Mf}$ was modified with ribose at $30^{\circ} \mathrm{C}$ for $2 \mathrm{~h}(23 \%$ of available lysine was modified), as shown in Table 1 . However, as the reaction advanced, a marked decrease was observed in the amount of solubilized myosin with a decrease in ketoamine content, whereas actin decreased slowly. This indicates that the decrease in the total solubility of the glycosylated Mf 
Table 1. Changes in available lysine and ketoamine contents and solubility of protein components in Mf during glycosylation

\begin{tabular}{|c|c|c|c|c|}
\hline \multirow{2}{*}{$\begin{array}{l}\text { Reaction } \\
\text { time (h) }\end{array}$} & \multirow{2}{*}{$\begin{array}{c}\text { Available } \\
\text { lysine } \\
\text { ( } \mu \text { mole } / \mathrm{g})\end{array}$} & \multirow{2}{*}{$\begin{array}{c}\text { Ketoamine } \\
(\mu \text { mole } / \mathrm{g})^{* 1}\end{array}$} & \multicolumn{2}{|c|}{ Ratio of soluble protein $(\%)^{*_{2}}$} \\
\hline & & & Myosin heavy chain & Actin \\
\hline 0 & 666 & 0 & 0 & 12 \\
\hline 2 & 526 & 40 & 72 & 80 \\
\hline 4 & 439 & 56 & 60 & 72 \\
\hline 8 & 286 & 25 & 19 & 57 \\
\hline
\end{tabular}

$*_{1}$ Fructosamine equivalent. ${ }^{*}$ See Reference No. 5 .

shown in Fig. 1 was caused by the insolubilization of myo$\sin$ as the Maillard reaction progressed. Therefore, glycosylation by the Maillard reaction in the early stage is quite important for improving the solubility of Mf by glycosylation with ribose.

\section{References}

1) M. Morales, C. W. Dill, and W. A. Landmann: J. Food Sci., 41, 234-236 (1976).

2) Y. Kato, K. Watanabe, and Y. Sato: J. Food Sci., 46, 1835-1839 (1981).

3) Y. Kato, T. Matsuda, and R. Nakamura: Biosci. Biotech, Biochem., 57, 1-5 (1993)

4) M. Wahyuni, M. Ishizaki, and M. Tanaka: Fisheries Sci., 64, 973978 (1998).

5) H. Saeki and K. Inoue: J. Agric. Food Chem., 45, 3419-3422 (1997).

6) K. Fujiwara, T. Oosawa, and H. Saeki: J. Agric. Food Chem., 46 1257-1261 (1998).

7) G. Gomori: J. Lab. Clinic. Med., 27, 955-960 (1942).

8) M. J. Medina Hernandez and M. C. Guarcia Alvarez-Coque: $J$. Food Sci., 57, 503-505 (1992).

9) R. N. Johnson, P. A. Metcalf, and J. R. Baker: Clin. Chim. Acta., 127, 87-95 (1982). 